\title{
Constructed Wetlands as a Natural Resource for Water Quality Improvement in Malaysia
}

\author{
Syafiq Shaharuddin, Ngai Weng Chan*, Nor Azazi Zakaria, Aminuddin Ab Ghani, \\ Chun Kiat Chang, Ranjan Roy \\ River Engineering and Urban Drainage Research Center (REDAC), Universiti Sains Malaysia, Nibong Tebal, \\ Malaysia \\ Email: "nwchan@usm.my
}

Received 3 March 2014; revised 5 April 2014; accepted 21 April 2014

Copyright (C) 2014 by authors and Scientific Research Publishing Inc.

This work is licensed under the Creative Commons Attribution International License (CC BY). http://creativecommons.org/licenses/by/4.0/

C) (i) Open Access

\section{Abstract}

Tropical wetlands have numerous natural functions, one of which is the filtration of wastewater for water quality improvement. The aim of this paper is to investigate the performance of constructed wetlands in Universiti Sains Malaysia for water quality treatment of stormwater runoff. A total of 17 sampling stations were selected from different sections of possessing different compositions, characteristics and plant species. Weekly physico-chemical and biological parameters were analysed during the one year period starting from December 2010 to December 2011. The results exhibited significant improvement of water quality as the concentration of nitrate, nitrite, ammoniacal-nitrogen, orthophosphate, TSS, BOD and COD decreased after the water passed through the macrophyte and micropool zones before being discharged to the wetland outlet. The concentration of nitrite was significantly reduced $(80 \%)$; nitrate $(61.56 \%)$, ammoniacal-nitrogen $(51.49 \%)$, orthophosphate $(60.98 \%)$, TSS $(67.86 \%)$, BOD $(27.7 \%)$ and COD $(46.43 \%)$. The decrease in the concentrations of the above pollutants showed that the improvement of water quality was performed in the wetland. Most of the concentrations fall in Class IIA and IIB based on National Water Quality Standards for Malaysia and Department of Environment (DOE) Water Quality Index Classification. Biological measurement showed high diversity of species. Based on the results obtained, the macrophyte zone showed a high number of species and percentage distribution of phytoplankton and zooplankton, starting from the Wetland 1and 2 until the outlet wetland (14.6\% 14.9\% until 3.5\%). While for fish distribution, Oreochromis niloticus was the dominant fish species from the others seven species found in the constructed wetland. Overall, the results from this study demonstrate that constructed wetlands significantly improve water quality of stormwater runoff, and that they are a good natural resource for the sustenance and maintenance of biodiversity.

*Corresponding author. 


\section{Keywords}

\section{Constructed Wetland, Water Quality, Biodiversity, Stormwater Runoff}

\section{Introduction}

In wet equatorial countries with high intensity rainfalls, stormwater runoff has not only caused severe flooding but also pollution of surface waters [1] [2]. Consequently, issues related to stormwater runoff have become one of the priority agendas of government and non-government sectors, local authorities, agencies and developers all around the world in order to solve the problems of urban runoff and water pollution in rapidly urbanizing areas. Urban runoff and subsequent pollution have serious effects on water resources that need to be addressed [3]. Urban stormwater runoff is well recognized as one of the major source of pollution that could adversely affect water quality if the runoff is discharged untreated. Another impact from stormwater runoff is habitat-destroying, which can cause harm to many wildlife population such as fish and birds, and also can kill the native vegetation, which is the primary building in the pyramid chain. Malaysia is taking a proactive step by implementing a new Urban Drainage Manual in 2000 known as Urban Stormwater Management Manual for Malaysia (MSMA) [4]. A pilot project, entitled Bio-Ecological Drainage System (BIOECODS), was carried out at Universiti Sains Malaysia (USM) Engineering Campus based on 1st Edition of MSMA and the design was continuously improve in the $2^{\text {nd }}$ Edition of MSMA. A constructed wetland which is one of the components in BIOECODS was built in order to provide ecological and biological stormwater treatment after purification through infiltration in swale and settling in wet pond and detention pond. The aim of the present study is to investigate the performance of constructed wetland in BIOECODS system for water quality treatment from stormwater runoff as well as the performance from species and biodiversity composition.

\section{Material and Methods}

The constructed wetland in this study is located in the Universiti Sains Malaysia (USM) Engineering Campus, lies between latitudes $100^{\circ} 29.5^{\prime}$ South and $100^{\circ} 30.3^{\prime}$ North and between longitudes $5^{\circ} 9.4^{\prime}$ East and $5^{\circ} 8.5^{\prime}$ West. In this study, seventeen sampling stations were identified and chosen as the study sites (Figure 1). The sampling area consists of Inlet Wetland (Inlet Wet) which is located at the inlet wetland, Wetland 1 (W1) located on the right bank and Wetland 2 (W2) located on the left bank, after the inlet wetland. For the Wetland 3 (W3), 4 (W4), 5 (W5) and 6 (W6), the station located in the middle of wetland, with W3 and W5 located right bank and W4

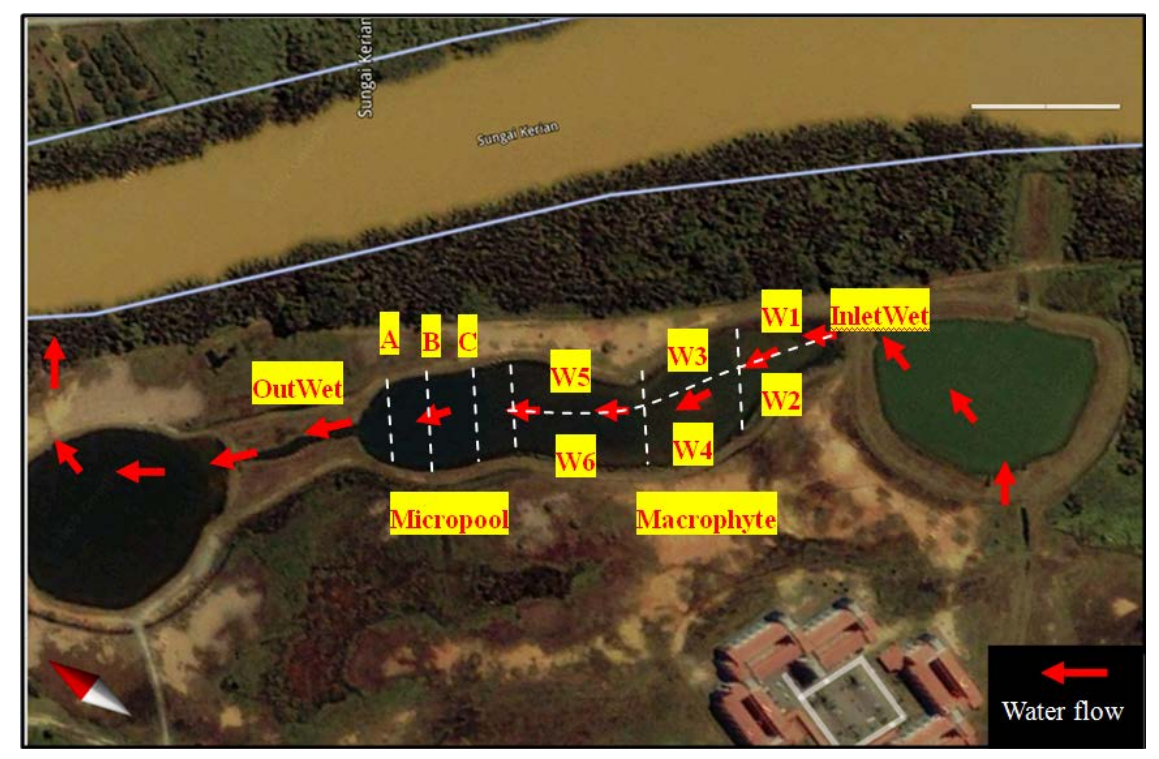

Figure 1. Sampling stations in the study area of constructed wetland USM. 
and W6 at the left bank. The area from Inlet Wetland until Wetland 5 and 6 are called Macrophyte Zone. The Micropool was divided into three rows (Micropool (M); MA, MB, MC) and each row consists of 3 equal distances (15 meter) point of station. The sampling station was chosen based on the consideration of certain numbers of aspects such as type of macrophyte or wetland plants and range of water depth. Different depth affects settlement process, treatment of water quality and distribution of biodiversity. Different wetland plants and densities of plant affect the treatment and nutrient uptake process. Figure 2 shows the cross section and range of depths of stations in USM Wetland.

Basically, the wetland was design based on 3 month ARI [5]. The general design criteria of constructed wetland can be seen in the Table 1 and Table 2 below shows type of macrophyte present at the macrophyte zone (W1 - W6). The design criteria are based on Stormwater Management Manual for Malaysia (MSMA).

Sampling procedure was separated into two procedures, biological sampling and water quality sampling. Three types of species or indicators [6] had been chosen to study the biodiversity; phytoplankton, zooplankton, freshwater fish. The water samples were collected using grab sample. The in-situ parameter was taken at the sampling stations during the sampling. The parameters that involved are the physico-chemical parameter including temperature, $\mathrm{pH}$, dissolved oxygen and conductivity. The nutrient parameter, duplicate bottles were used to run the analysis in the lab. The types of analysis were total suspended solid (TSS), nitrite $\mathrm{NO}_{2}^{-}$, nitrate $\mathrm{NO}_{3}^{-}$, ammoniacal nitrogen $\mathrm{NH}_{3}-\mathrm{N}$, biochemical oxygen demand (BOD), chemical oxygen demand (COD), and Ortho-phosphate.

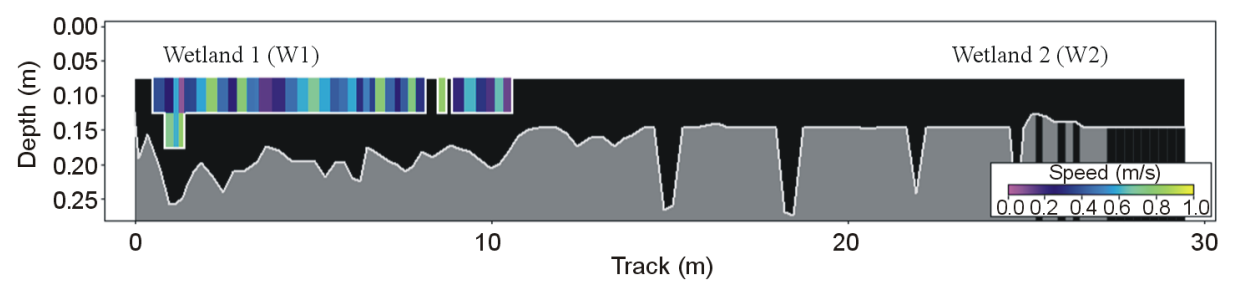

Range of water depth: 0.51 - 0.62 m (W3-W4)

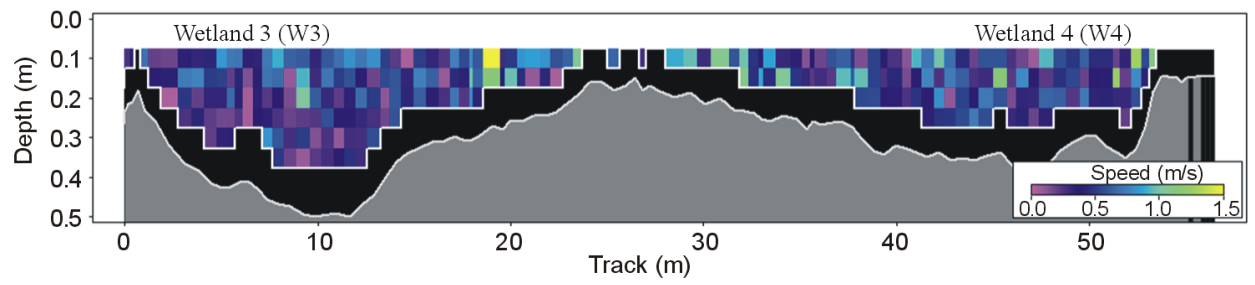

Range of water depth: 0.51 - 0.62 m (W3-W4)

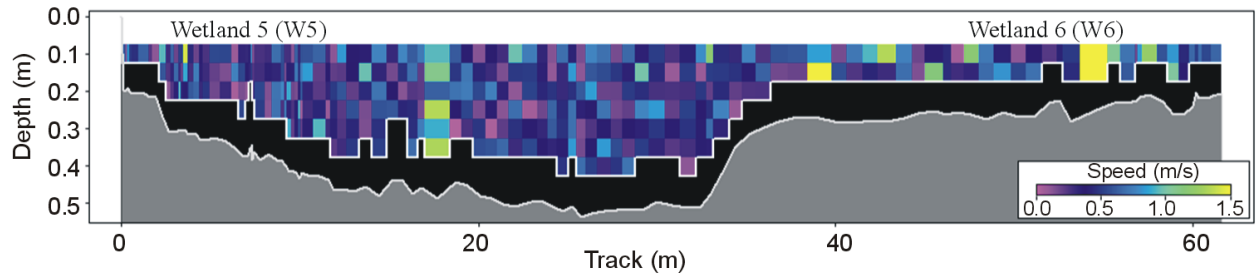

Range of water depth: 0.51 - 0.64 m (W5-W6)

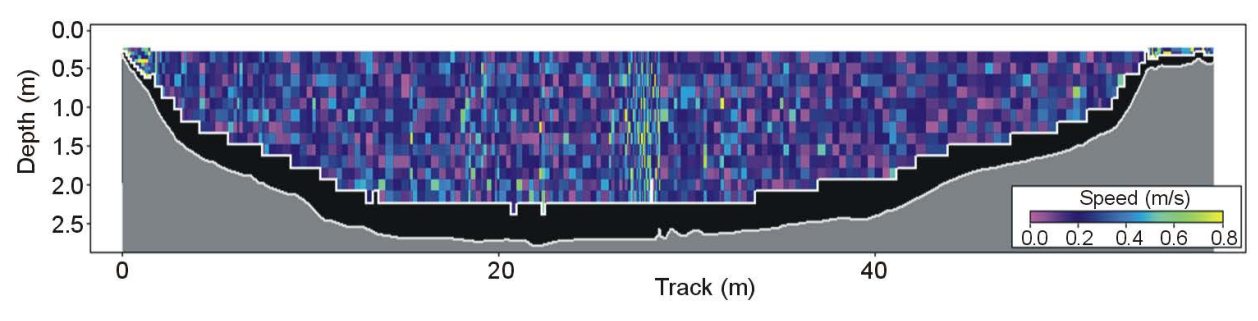

Range of water depth: 2.51 - 2.54 m (Micropool)

Figure 2. Cross section and range of depth of station in USM Wetland. 
Table 1. Design criteria for the constructed wetland, USM.

\begin{tabular}{cc}
\hline Contributing drainage area & $1011,714.11 \mathrm{~m}^{2}$ \\
Water quality volume (WQV) & $14,164 \mathrm{~m}^{3}$ \\
Length & $250 \mathrm{~m}$ \\
Width & $50 \mathrm{~m}$ \\
Length to width ratio & $5: 1$ \\
Wetland surface area & $12,500 \mathrm{~m}^{2}$ \\
Water depth & $0.3-1.0 \mathrm{~m}$ \\
Extended detention depth & $1.2 \mathrm{~m}$ \\
Wetland volume & $16,312 \mathrm{~m}^{2}$ \\
\% Catchment area & 0.7 \\
Design inflow rate & $0.25 \mathrm{~m}^{3} / \mathrm{s}$ \\
Mean residence time & 3 days \\
Mediae & Pea gravel and soil mixture \\
Hydraulic conductivity of gravel & $10^{-3} \mathrm{~m} / \mathrm{s} \mathrm{to} 10^{-2} \mathrm{~m} / \mathrm{s}$ \\
\hline
\end{tabular}

Table 2. Wetland plant in macrophyte zone.

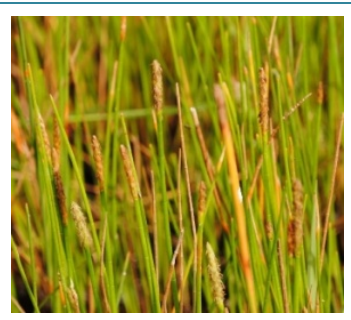

Eleocharis variegata (Spike rush)

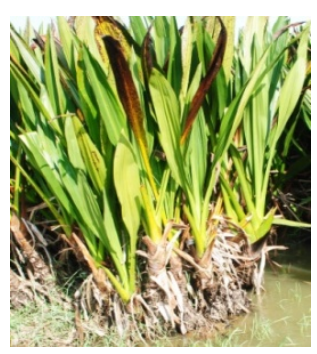

Hanguana malayana (Common Hanguana)

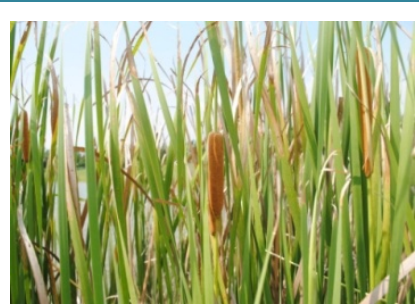

Typha angustifolia (Cat-tail)

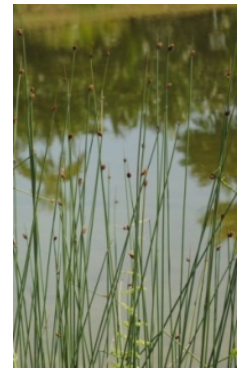

Lepironia articulata (Tube sedge)

\section{Results}

\section{Water Quality}

Table 3 showed the mean and range value for each parameter measured at 17 sampling stations starting from December 2010 until December 2011. The standard deviation varied for each parameter, which some parameter showed low standard deviation (DO, pH, Nitrite, Nitrate, Ammoniacal Nitrogen, ortho-phosphate and BOD) while other showed high standard deviation (conductivity, COD, TSS and Temperature). The lowest standard deviation indicated that the value tend to be very close to mean value while highest standard deviation indicated that the values spread out over a large range of values.

Based on the results obtained in Table 3, most of the nutrient analysis show some reduction after the stormwater flowed through the wetland. For nitrite concentration reduce from $0.035 \mathrm{mg} / \mathrm{l}$ to 0.007 , remove $80 \%$; 
Table 3. Mean for water quality parameters for 17 sampling stations for 13 month period (December 2010-December 2011).

\begin{tabular}{|c|c|c|c|c|c|c|c|c|c|c|c|c|}
\hline Station & $\begin{array}{c}\text { Temp. } \\
{ }^{\circ} \mathrm{C}\end{array}$ & $\begin{array}{c}\text { Cond. } \\
\left(\mu \mathrm{S} \cdot \mathrm{cm}^{-1}\right)\end{array}$ & $\begin{array}{c}\mathrm{DO} \\
\left(\mathrm{mg} \cdot 1^{-1}\right)\end{array}$ & $\mathrm{pH}$ & $\begin{array}{l}\text { Nitrite } \\
\left(\mathrm{mg} \cdot l^{-1}\right)\end{array}$ & $\begin{array}{l}\text { Nitrate } \\
\left(\mathrm{mg} \cdot l^{-1}\right)\end{array}$ & $\begin{array}{l}\text { PO4-P } \\
\left(\mathrm{mg} \cdot 1^{-1}\right)\end{array}$ & $\begin{array}{l}\text { NH4-N } \\
\left(\mathrm{mg} \cdot 1^{-1}\right)\end{array}$ & $\begin{array}{c}\text { BOD } \\
\left(\mathrm{mg} \cdot \mathrm{l}^{-1}\right)\end{array}$ & $\begin{array}{l}\mathrm{COD} \\
\left(\mathrm{mg} \cdot \mathrm{l}^{-1}\right)\end{array}$ & $\begin{array}{c}\text { TSS } \\
\left(\mathrm{mg} \cdot \mathrm{l}^{-1}\right)\end{array}$ & Class \\
\hline Inlet Wet & 31.59 & 138 & 8.04 & 7.65 & 0.035 & 2.94 & 0.41 & 0.303 & 2.78 & 28 & 28 & IIB \\
\hline W1 & 32.05 & 141 & 8.26 & 7.71 & 0.032 & 3.43 & 0.40 & 0.324 & 3.30 & 30 & 29 & IIB \\
\hline W2 & 31.90 & 141 & 8.05 & 7.72 & 0.030 & 3.32 & 0.40 & 0.326 & 3.35 & 29 & 27 & IIB \\
\hline W3 & 31.94 & 138 & 8.67 & 7.84 & 0.027 & 2.84 & 0.33 & 0.288 & 2.89 & 24 & 24 & IIB \\
\hline W4 & 31.55 & 139 & 8.57 & 7.93 & 0.023 & 2.88 & 0.30 & 0.285 & 2.71 & 24 & 23 & IIB \\
\hline W5 & 31.60 & 140 & 8.31 & 7.78 & 0.016 & 2.48 & 0.29 & 0.267 & 2.78 & 25 & 22 & IIA \\
\hline W6 & 31.38 & 138 & 8.74 & 7.75 & 0.017 & 2.48 & 0.26 & 0.257 & 2.68 & 24 & 22 & IIA \\
\hline MC 1 & 30.85 & 136 & 8.13 & 7.88 & 0.013 & 2.00 & 0.22 & 0.218 & 2.44 & 23 & 17 & IIA \\
\hline M C 2 & 30.88 & 137 & 8.18 & 7.82 & 0.009 & 1.90 & 0.21 & 0.209 & 2.39 & 21 & 16 & IIA \\
\hline M C3 & 31.01 & 137 & 8.20 & 7.80 & 0.009 & 1.92 & 0.22 & 0.191 & 2.36 & 21 & 15 & IIA \\
\hline MB 1 & 30.59 & 135 & 8.09 & 7.78 & 0.008 & 1.80 & 0.20 & 0.180 & 2.24 & 20 & 13 & IIA \\
\hline MB 2 & 30.71 & 136 & 8.01 & 7.77 & 0.009 & 1.67 & 0.19 & 0.174 & 2.40 & 19 & 14 & IIA \\
\hline MB 3 & 30.79 & 136 & 8.11 & 7.80 & 0.010 & 1.66 & 0.18 & 0.171 & 2.33 & 17 & 13 & IIA \\
\hline MA 1 & 30.53 & 132 & 8.04 & 7.26 & 0.009 & 1.43 & 0.17 & 0.165 & 2.36 & 19 & 11 & IIA \\
\hline MA 2 & 30.53 & 134 & 8.03 & 7.70 & 0.009 & 1.38 & 0.16 & 0.160 & 2.19 & 18 & 11 & IIA \\
\hline MA 3 & 30.58 & 134 & 7.95 & 7.72 & 0.009 & 1.36 & 0.16 & 0.151 & 2.08 & 16 & 10 & IIA \\
\hline Outlet Wet & 30.00 & 133 & 7.78 & 7.60 & 0.007 & 1.13 & 0.16 & 0.147 & 2.01 & 15 & 9 & IIA \\
\hline $\begin{array}{l}\text { Percentage } \\
\text { removal (\%) }\end{array}$ & - & - & - & - & 80 & 61.56 & 60.98 & 51.49 & 27.7 & 46.43 & 67.86 & \\
\hline
\end{tabular}

nitrate reduce from $2.94 \mathrm{mg} / \mathrm{l}$ to $1.13 \mathrm{mg} / \mathrm{l}$ remove $61.56 \%$, ammoniacal-nitrogen reduce from $0.303 \mathrm{mg} / \mathrm{l}$ to $0.147 \mathrm{mg} / \mathrm{l}$, remove $51.49 \%$, orthophosphate reduce from $0.41 \mathrm{mg} / \mathrm{l}$ to $0.16 \mathrm{mg} / \mathrm{l}$, remove $60.98 \%$, TSS reduce from $28 \mathrm{mg} / \mathrm{l}$ to $9 \mathrm{mg} / \mathrm{l}$, remove $67.86 \%$, BOD reduce from $2.78 \mathrm{mg} / \mathrm{l}$ to $2.01 \mathrm{mg} / \mathrm{l}$, remove $27.7 \%$ and COD reduce from $28 \mathrm{mg} / \mathrm{l}$ to $15 \mathrm{mg} / \mathrm{l}$, remove 46.43\%. Most of the concentration laid on Class IIB and Class IIA. The improvement shown was due to favorable physic-chemical such as high dissolve oxygen and average level of water temperature. Plant uptake is also one of the factor involve to this improvement and help to reduce to input nutrient concentration. Macrophyte, which dense with plant, helps to polish the nutrient concentration as well as provide favorable habitat for wildlife to live. Figures 3(a)-(c) showed the results of biological measurement and observation from phytoplankton, zooplankton and freshwater fish. Based on the Figure 3(a), high percentage of species distribution, which was in the range 14.6 to $14.9 \%$ and number of individual species, from 1922 ind. species to 1959 ind. species, found in Wetland 1 and 2 (W1 and W2). The lowest data recorded for phytoplankton found in the inlet wetland. The pattern in the graph showed the number of individual species and percentage distribution is decreasing until it reach outlet wetland (3.5\% and 461 ind. species). The same situation obtained for zooplankton data in the Figure 3(b), whereas the highest percentage of species distribution and number of ind. species recorded in W1 (14.1\% and 539 ind. species) and the lowest found in inlet wetland (3.5\% and 135 ind. species). The trend of distribution in the wetland for zooplankton was almost like phytoplankton result, which is the percentage species distribution and number of individual species is decreasing until it reach outlet wetland (3.9\% and 150 ind. species). The distribution of phytoplankton and zooplankton are closely related to the water quality measure and nutrient availability. Less nutrient concentration supply will affect the distribution of phytoplankton and zooplankton species became lower. 7 different freshwater fish was caught and identified in the constructed wetland throughout the sampling period. The highest distribution based on the number of species caught was Oreochromis niloticus, 30\% out of others species caught, followed by Barbodes schawanenfeldii, Colossoma macropomum, Labeo rohita (each species contribute 15\% of percentage distribution), Oxyeleotris marmoratus (10\%), Barbodes gonionotus (10\%), Channa micropleti, Channa striata, and Pangasius spp (contribute 5\%). The abundance of fish mostly centralizes in the micropool area due to favorable area and water depth except for Oxyeleotris marmoratus, which highly found the shallow area (W1 until W6). 


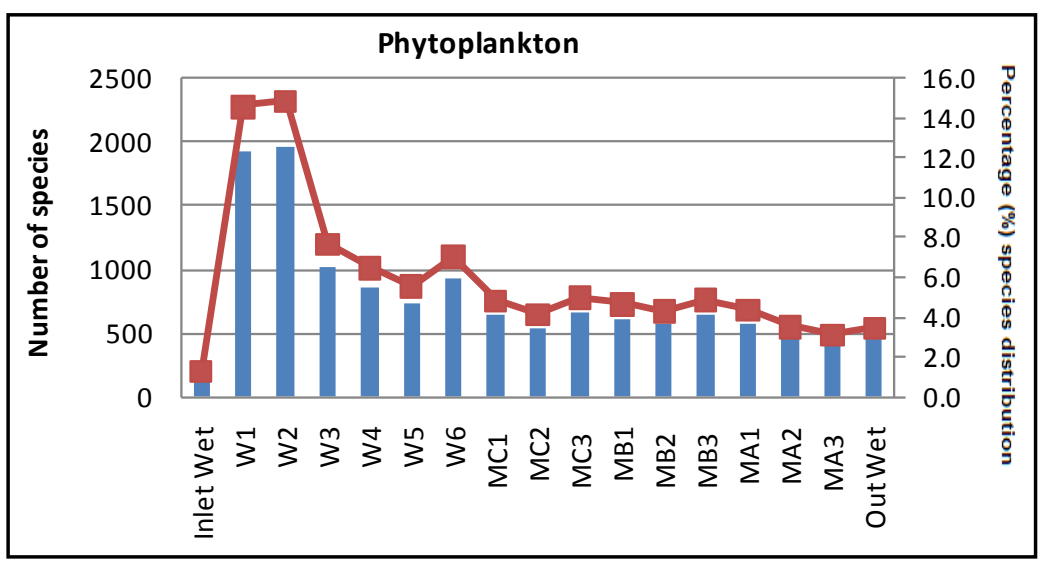

(a)

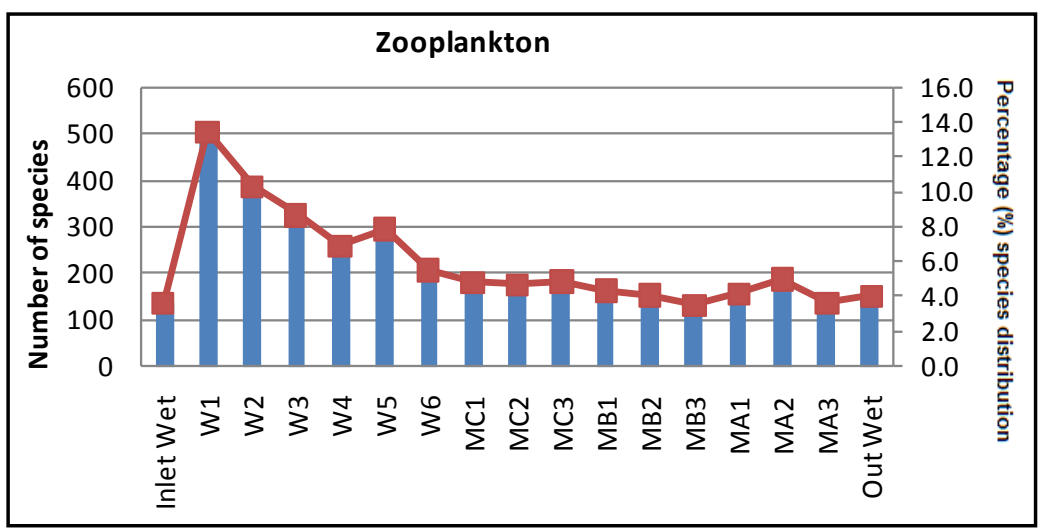

(b)

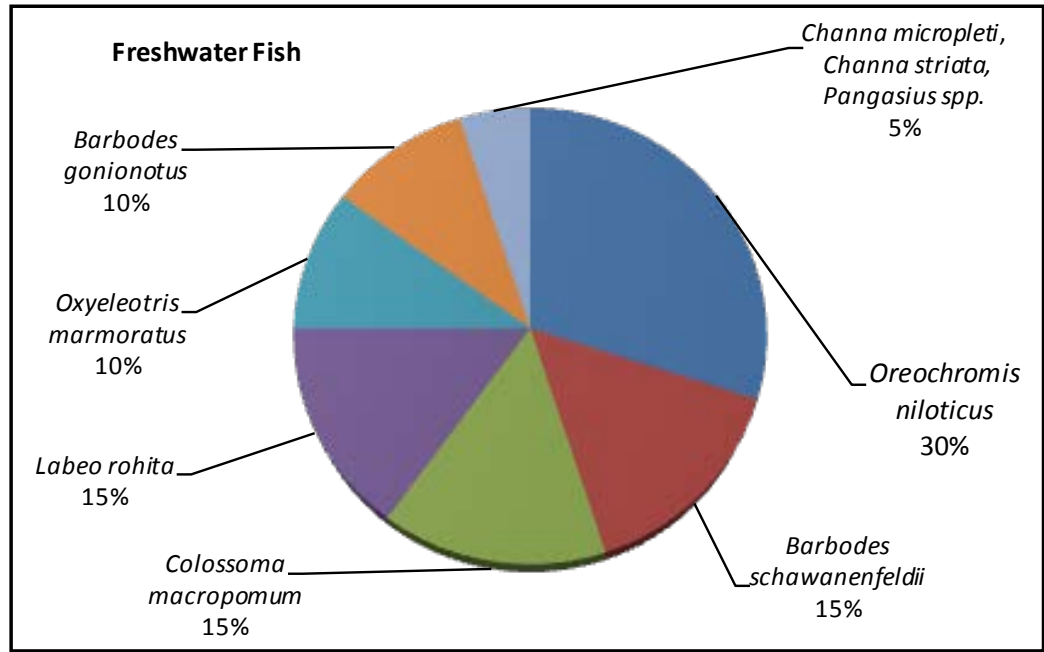

(c)

Figure 3. Graph for biological measurement: (a) Percentage distribution and number of species for phytoplankton; (b) Percentage distribution and number of species for zooplankton; and (c) Percentage distribution of freshwater fish.

\section{Discussion and Conclusion}

Mohammad Baneshi et al. [7] have shown that plants such as Sorghum and Onobrychis sativa can be used effectively to remove pollutants from soil via bioaugmentation. This paper has shown that the pollution effects of 
dirty urban stormwater runoffs can be addressed by using constructed wetlands. Such wetlands can be easily constructed in housing areas, municipal parks, along river floodplains and wherever there is empty land in the city. It needs political will and prudent urban planning within an enabling environment of integrated water resources management to ensure constructed wetlands are put into the government agenda [8] [9]. In the case of Malaysia, the use of constructed wetlands for flood attenuation and pollution control remains an important challenge in water resources governance [10]. The results showed that pollutants such as nitrite, nitrate, ammoniacal nitrogen and phosphate were significantly reduced after the stormwater passed through the constructed wetland. Their concentrations were significantly reduced from the macrophyte area (Wetland 1 and Wetland 2) until the Micropool area. The area design for the wetland and the present of dense vegetation in the macrophyte area help to reduce the concentration of the total suspended solid as well as the COD and BOD levels. This study confirms and concludes that the USM constructed wetland possess high dissolve oxygen (DO) and favourable water temperature, with the range between $28^{\circ} \mathrm{C}-32^{\circ} \mathrm{C}$, and most of the time neutral in $\mathrm{pH}$, helped to maintain the ecological quality with diverse biodiversity. The improvement of water quality had created sustainable habitats for wildlife to live, starting from low trophic level to species of higher trophic levels. Wetlands therefore had positively enhanced the water security for humans, but also for ecosystem and species biodiversity.

\section{Acknowledgements}

The authors wish to acknowledge the support from the Malaysian Ministry of Education LRGS Project 203/PKT/6720004, the Ministry of Science and Technology of China (2008CB425803) and State Key Lab of Water Science and Engineering (2009-ZY-2).

\section{References}

[1] Chan, N.W., Zakaria, N.A., Ab Ghani, A. and Lian T.Y. (2004) Integrating Official and Traditional Flood Hazard Management in Malaysia. In: Ab Ghani, A., Zakaria, N.A., Abdullah, R. and Ahmad, M.S.S., Eds., Rivers '04 Proceedings of the 1st International Conference on Managing Rivers in the 21st Century: Issues \& Challenges, River Engineering and Urban Drainage Research Centre (REDAC), Universiti Sains Malaysia, 409-419.

[2] Chan, N.W. (2012) Managing Urban Rivers and Water Quality in Malaysia for Sustainable Water Resources. International Journal of Water Resources Development, 28, 343-354. http://dx.doi.org/10.1080/07900627.2012.668643

[3] Chan, N.W. (2006) A Comparative Study of Water Resources Usage by Households in Georgetown-Malaysia and Pattaya-Thailand. Iranian Journal of Environmental Health Science \& Engineering, 3, 223-228.

[4] Musa, S.M.B.S. and Chan, N.W. (2011) Pengurusan Banjir di Malaysia: Pendekatan Baru Berfokus Manual Saliran Mesra Alam (MSMA). In: Jahi, J.Md., Razman, M.R., Arifin, K., Efizon, D., Hasan, B., Aiyub, K., Awang, A. and Zakaria, S.Z.S., Eds., Perubahan Persekitaran Di Alam Melayu: Prosiding Seminar Antarabangsa Ke-4 Ekologi, HabitatManusia \& Perubahan Persekitaran di Alam Melayu. Universiti Kebangsaan Malaysia, Bangi, 896-904.

[5] MoNRE (Ministry of Natural Resources and Environment) (2011) Urban Stormwater Management Manual. Ministry of Natural Resources and Environment, Malaysia.

[6] Roy, R., Chan, N.W. and Rainis, R. (2013) Development of Indicators for Sustainable Rice Farming in Bangladesh: A Case Study with Participative Multi-Stakeholder Involvement. World Applied Sciences Journal, 22, 672-682.

[7] Baneshi, M., Kalantary, R.R., Jafari, A.J., Nasseri, S., Jaafarzadeh, N. and Esrafili, A. (2014) Effect of Bioaugmentation to Enhance Phytoremediationfor Removal of Phenanthrene and Pyrene from Soil with Sorghum and Onobrychis Sativa. Journal of Environmental Health Science and Engineering, 12, 24. http://dx.doi.org/10.1186/2052-336X-12-24

[8] Roy, R., Chan, N.W., Uemura, T. and Imura, H. (2013) The Vision of Agri-Environmental Sustainability in Bangladesh: How the Policies, Strategies and Institutions Delivered? Journal of Environmental Protection, 4, 40-51. http://dx.doi.org/10.4236/jep.2013.48A2006

[9] Roy, R. and Chan, N.W. (2014) A Multi-Level Evaluation of Policy Integration of Human Resource Development in Agriculture Sector. Natural Resources, 5, 119-129. http://dx.doi.org/10.4236/nr.2014.54013

[10] Chan, N.W. (2009) Issues and Challenges in Water Governance in Malaysia. Iranian Journal of Environmental Health Science \& Engineering, 3, 143-152. 